\title{
A study of intra-operative maternal morbidity after repeating caesarean section
}

\author{
Sonali S. Somani ${ }^{1 *}$, Sunita Sudhir ${ }^{1}$, Shashikant G. Somani ${ }^{2}$, Bushra ${ }^{1}$
}

\begin{abstract}
${ }^{1}$ Department of Obstetrics and Gynecology, ${ }^{2}$ Department of Physiology, Kamineni Institute of Medical Science, Narketpally, Nalgonda (Dist.) Telangana, India
\end{abstract}

Received: 31 October 2017

Accepted: 25 November 2017

\section{*Correspondence:}

Dr. Sonali S. Somani,

E-mail: drsgsomani@gmail.com

Copyright: () the author(s), publisher and licensee Medip Academy. This is an open-access article distributed under the terms of the Creative Commons Attribution Non-Commercial License, which permits unrestricted non-commercial use, distribution, and reproduction in any medium, provided the original work is properly cited.

\begin{abstract}
Background: Caesarean section (CS) is one of the most common obstetric procedures worldwide and an increased rate of caesarean section has been observed in recent studies. Maternal morbidities and mortality associated with repeat caesarean section is an important health problem. The present study aims at knowing the various intraoperative complications encountered during repeat caesarean sections. Objective was to study the incidence and type of surgical difficulties encountered in repeat cesarean sections

Methods: It was a prospective observational study of 118 cases of repeat cesarean sections. Intra-operative findings of all cases were analyzed to know the difficulties encountered because of previous cesarean section.

Results: In present study, out of total 118 cases of previous cesarean sections, $71(60.17 \%)$ cases were of previous one caesarean section and $47(39.83 \%$ ) were of previous two cesarean sections. Following intraoperative morbidities were encountered - adhesions ( 1 caesarean section vs 2 caesarean section -40.85 vs $65.96 \%$ respectively), thin lower uterine segment ( 1 caesarean section vs 2 caesarean section - 21.13 vs $36.17 \%$ respectively), advanced bladder(1 caesarean section vs 2 caesarean section -15.49 vs $36.17 \%$ respectively), extension of uterine incision( 1 caesarean section vs 2 caesarean section - 9.86 vs $19.15 \%$ respectively), scar dehiscence( 1 caesarean section vs 2 caesarean section -7.04 vs $31.91 \%$ respectively), excess blood loss ( 1 caesarean section vs 2 caesarean section -7.04 vs $19.15 \%$ respectively), 1 case of placenta accrete was found in previous 2 caesarean section $2.13 \%$ ) which needed caesarean hysterectomy. uterine rupture and bladder injury seen in one patients of previous 2caesarean section. Time taken for surgery was more in repeat CS group Delivery.

Conclusions: An increasing number of $\mathrm{CS}$ is accompanied by increased maternal morbidity. Intraoperative complication which increase the risk of morbidity are adhesion, placenta accreta. It is prudent to involve a senior experienced obstetrician in repeat cesarean section. The best way to reduce this is by reducing primary caesarean section rates. Patients with previous caesarean section should be considered as high risk and should be counseled for regular antenatal check-up and they should be given option of vaginal birth after CS whenever possible.
\end{abstract}

Keywords: Intra-operative complications, Morbidity, Repeat cesarean section

\section{INTRODUCTION}

Lower segment caesarean section (LSCS) is one of the most common obstetric procedures worldwide. Its relative safety has accelerated the acceptance and rate in recent years and this is now a public health problem in terms of economical burden and possible complications. Main reasons for this increase: rapidly decreasing rate of vaginal birth after cesarean section (VBAC) and increasing primary cesarean rate on maternal request. ${ }^{1}$ Although, operation is now safer than in the past because of improvements in anaesthesia, antibiotics and blood 
transfusion services, still it carries a significant risk to the mother compared to vaginal delivery. Complications of caesarean section can result from many factors including timing of the procedure, surgical technique, and clinician experience. Repeat cesarean section makes future obstetrics performances and abdominal exploration more risky. The risk of complications increases with increasing number of cesarean section, the well known complications are intraabdominal dense adhesions, morbid adherent placenta, uterine dehesince/ uterine scar rupture with subsequent adverse fetal and maternal outcome, bowel and bladder injury and cesarean hysterectomy. ${ }^{2-5}$ The present study aims to know the surgical difficulties encountered by a obstretician in repeat cesarean section.

\section{METHODS}

Present study was conducted at Department of Obstetrics and Gynecology in Kamineni Institute of Medical Sciences, Narketpally from January 2015 to December 2015. It was a Pospective observational study conducted on 118 cases of repeat cesarean section. The research protocol was approved by the Institutional Ethics Committee. An informed consent was taken. Patients were selected according to inclusion and exclusion criteria.

\section{Inclusion criteria}

All previous cesarean section.

\section{Exclusion criteria}

- First cesarean section

- H/o abdominal surgeries.

Sample size was calculated as 118 according to the equation

$\mathrm{n}=\mathrm{p} *(1-\mathrm{p}) / \mathrm{L} 2$

Where, $\mathrm{p}=$ prevalence of CS in our hospital, $\mathrm{L}=$ sample size in studies, $\mathrm{n}=$ sample size in our study

Obstreticians were requested to note difficulties they encountered while operating on cases of previous cesarean section. The intraoperative complications were compared with respect to adhesions (peritoneal, bladder, bowel, omental etc), blood loss, extension of tears over uterus, bladder injury, scar dehiscence, uterine rupture, need for hysterectomy etc.

The primary outcome measures were the incidence and extent of adhesion. Adhesions were categorized as flimsy and dense.

The inter-delivery interval (time to delivery), and the operating time (defined as skin incision to skin closure) were noted.

\section{Statistical analysis}

Women were categorized on the basis of the number of caesarean deliveries that they had undergone (1 and 2). The frequency of occurrence of each outcome measure was captured.

All statistical calculations were done using computer programs Microsoft Excel 2007 and SPSS version 21. Numbers and percentages were calculated for qualitative variables and the continuous variables were presented as mean \pm standard deviation.

Comparisons between mean values of quantitative variables were calculated using Student $t$ test and chisquare was used for qualitative data. A probability value ( $\mathrm{p}$ value) less than 0.05 was considered statistically significant.

\section{RESULTS}

In present study, out of total 118 cases of previous cesarean sections, $71(60.17 \%)$ cases were of previous one cesarean section and $47(39.83 \%)$ were of previous two cesarean sections (Table 1).

Table 1: Number of previous cesarean sections.

\begin{tabular}{|lll|}
\hline $\begin{array}{l}\text { Number of } \\
\text { previous LSCS }\end{array}$ & $\begin{array}{l}\text { Number of patients } \\
(\mathbf{N}=118)\end{array}$ & $\%$ \\
\hline Previous 1 & 71 & 60.17 \\
\hline Previous 2 & 47 & 39.83 \\
\hline
\end{tabular}

Table 2 shows various intraoperative complication observed with previous caesarean section. One can note complications increased with number of CS. This table shows that frequency of adhesion is very high among pregnant women undergoing repeated caesarean section.

Table 2: Intraoperative maternal morbidity during repeat cesarean sections.

\begin{tabular}{|c|c|c|c|c|}
\hline \multirow{2}{*}{$\begin{array}{l}\text { Problem } \\
\text { encountered }\end{array}$} & \multicolumn{2}{|c|}{$\begin{array}{l}\text { Previous } 1 \\
\text { LSCS }(n=71)\end{array}$} & \multicolumn{2}{|c|}{$\begin{array}{l}\text { Previous } 2 \\
\text { LSCS }(n=47)\end{array}$} \\
\hline & $\begin{array}{l}\text { No. of } \\
\text { patients }\end{array}$ & $\%$ & $\begin{array}{l}\text { No. of } \\
\text { patients }\end{array}$ & $\%$ \\
\hline Adhesion & 29 & 40.85 & 31 & 65.96 \\
\hline Advance bladder & 11 & 15.49 & 17 & 36.17 \\
\hline Bladder injury & 0 & 0 & 1 & 2.13 \\
\hline Bowel injury & 0 & 0 & 0 & 0 \\
\hline $\begin{array}{l}\text { Thin lower } \\
\text { uterine segment }\end{array}$ & 15 & 21.13 & 17 & 36.17 \\
\hline Uterine dehiscence & 5 & 7.04 & 15 & 31.91 \\
\hline Uterine rupture & 0 & 0 & 1 & 2.13 \\
\hline $\begin{array}{l}\text { Extension of } \\
\text { uterine incision }\end{array}$ & 7 & 9.86 & 9 & 19.15 \\
\hline Placenta accreta & 0 & 0 & 1 & 2.13 \\
\hline Excess blood loss & 5 & 7.04 & 9 & 19.15 \\
\hline $\begin{array}{l}\text { Caesarean } \\
\text { hysterectomy }\end{array}$ & 0 & 0 & 1 & 2.13 \\
\hline
\end{tabular}


Intra peritoneal adhesions of varied types increased surgery duration by causing difficulties in opening abdomen and necessitating scar excision.

The urinary bladder was advanced (adherent at a higher level of anterior uterine wall) in $(36.17 \%)$ of the patients with two previous CS. The bladder was inadvertently injured in one case of two previous CS.

The incidence of thin LUS was found to be $21.13 \%$ in those with previous $1 \mathrm{CS}$ and $36.17 \%$ in those with previous $2 \mathrm{CS}$ and this implies that as the number of CS increase the chance of thin scar increases.

Scar dehiscence (1 caesarean section vs 2 caesarean section $-7.04 \%$ vs $31.91 \%$ respectively) and scar rupture was seen in $(2.13 \%)$ cases of previous 2 caesarean section. excess blood loss was noted in 7.04 vs 19.15 in 1 caesarean section vs 2 caesarean section respectively)

One case of $(2.13 \%)$ placenta accreta was found in 2 previous caesarean section which needed obstetric hysterectomy.

Table 3: Association of number of previous caesarean section with adhesion.

\begin{tabular}{|c|c|c|c|c|}
\hline \multirow{2}{*}{$\begin{array}{l}\text { H/o } \\
\text { caesarean } \\
\text { section }\end{array}$} & \multirow{2}{*}{$\begin{array}{l}\text { Total no. } \\
\text { of patients } \\
(\mathrm{N}=118)\end{array}$} & \multicolumn{2}{|c|}{ Adhesion } & \multirow{2}{*}{$\begin{array}{l}\mathrm{p} \\
\text { value }\end{array}$} \\
\hline & & Present & Absent & \\
\hline 1 & 71 & 29 & 42 & \multirow{2}{*}{$<0.05$} \\
\hline 2 & 47 & 31 & 16 & \\
\hline
\end{tabular}

Table 3 shows positive association of number of previous caesarean section with adhesion. As both of the variables are categorical, Chi-square test of independence was applied which was statistically significant $(\mathrm{p}<0.05)$.

Table 4: Site and extent of adhesion after repeat LSCS.

\begin{tabular}{|c|c|c|c|c|c|}
\hline \multicolumn{2}{|c|}{ Site of Adhesion } & \multicolumn{2}{|c|}{$\begin{array}{l}\text { Previous } 1 \\
\text { LSCS (n=29) }\end{array}$} & \multicolumn{2}{|c|}{$\begin{array}{l}\text { Previous } 2 \\
\text { LSCS (n=31) }\end{array}$} \\
\hline \multirow{2}{*}{$\begin{array}{l}\text { Uterus- } \\
\text { bladder }\end{array}$} & Flimsy & 8 & \multirow{2}{*}{$\begin{array}{l}13 \\
(44.83 \%)\end{array}$} & 3 & \multirow{2}{*}{$\begin{array}{l}9 \\
(29.03 \%)\end{array}$} \\
\hline & Dense & 5 & & 6 & \\
\hline \multirow{2}{*}{$\begin{array}{l}\text { Uterus- } \\
\text { omentum }\end{array}$} & Flimsy & 4 & \multirow{2}{*}{$\begin{array}{l}6 \\
(20.69 \%)\end{array}$} & 4 & \multirow{2}{*}{$\begin{array}{l}7 \\
(22.58 \%)\end{array}$} \\
\hline & Dense & 2 & & 3 & \\
\hline \multirow{2}{*}{$\begin{array}{l}\text { Uterus- } \\
\text { intestine }\end{array}$} & Flimsy & 1 & \multirow{2}{*}{$\begin{array}{l}1 \\
(3.45 \%)\end{array}$} & 1 & \multirow{2}{*}{$2(6.45 \%)$} \\
\hline & Dense & 0 & & 1 & \\
\hline \multirow{2}{*}{$\begin{array}{l}\text { Uterus- } \\
\text { abdominal } \\
\text { wall }\end{array}$} & Flimsy & 3 & \multirow{2}{*}{$\begin{array}{l}4 \\
(13.79 \%)\end{array}$} & 3 & \multirow{2}{*}{$\begin{array}{l}7 \\
(22.58 \%)\end{array}$} \\
\hline & Dense & 1 & & 4 & \\
\hline \multirow{2}{*}{$\begin{array}{l}\text { Uterus- } \\
\text { adenexa }\end{array}$} & Flimsy & 2 & \multirow{2}{*}{$\begin{array}{l}2 \\
(6.89 \%)\end{array}$} & 1 & \multirow{2}{*}{$3(9.68 \%)$} \\
\hline & Dense & 0 & & 2 & \\
\hline \multirow{2}{*}{$\begin{array}{l}\text { Omentum- } \\
\text { abdominal } \\
\text { wall }\end{array}$} & Flimsy & 2 & \multirow{2}{*}{$\begin{array}{l}3 \\
(10.34 \%)\end{array}$} & 1 & \multirow[b]{2}{*}{$3(9.68 \%)$} \\
\hline & Dense & 1 & & 2 & \\
\hline
\end{tabular}

Table 4 presents chances of adhesions are more in successive repeat caesarean section. The site of adhesions was predominant between Uterus-Bladder, UterusOmentum and Uterus-Abdominal wall.

Table 5: Delivery and operating time in the presence and absence of adhesion.

\begin{tabular}{|llll|}
\hline Number of Previous LSCS & $\begin{array}{l}\text { Delivery } \\
\text { time (min) }\end{array}$ & $\begin{array}{l}\text { Operating } \\
\text { time (min) }\end{array}$ \\
\hline $\begin{array}{l}\text { Previous 1 } \\
(\mathrm{n}=71)\end{array}$ & $\begin{array}{l}\text { Presence of } \\
\text { adhesion }(\mathrm{n}=29)\end{array}$ & $10.5 \pm 0.9$ & $42.01 \pm 0.5$ \\
\hline & $\begin{array}{l}\text { Absence of } \\
\text { adhesion }(\mathrm{n}=42)\end{array}$ & $8.5 \pm 0.7$ & $35.2 \pm 0.7$ \\
\hline $\begin{array}{l}\text { Previous 2 } \\
(\mathrm{n}=47)\end{array}$ & $\begin{array}{l}\text { Presence of } \\
\text { adhesion }(\mathrm{n}=31)\end{array}$ & $14.8 \pm 0.3$ & $55.03 \pm 2.6$ \\
\hline & $\begin{array}{l}\text { Absence of } \\
\text { adhesion }(\mathrm{n}=16)\end{array}$ & $9.5 \pm 0.6$ & $39.5 \pm 0.9$ \\
\hline
\end{tabular}

Table 5 shows delivery time was significantly more at subsequent caesarean delivery $(55.03 \pm 2.6$ vs $42.01 \pm 0.5$ mins). The delivery time and total operating time of the repeat caesarean deliveries among patients with adhesions are significantly longer. However, in repeat caesarean deliveries without adhesion, there are no significant time difference.

Table 6: Association of number of previous caesarean section with uterine dehiscence.

\begin{tabular}{|c|c|c|c|c|}
\hline \multirow{2}{*}{$\begin{array}{l}\text { History of } \\
\text { caesarean } \\
\text { section }\end{array}$} & \multirow{2}{*}{$\begin{array}{l}\text { Total no. of } \\
\text { patients } \\
(\mathrm{N}=118)\end{array}$} & \multicolumn{2}{|c|}{$\begin{array}{l}\text { H/o uterine } \\
\text { dehiscence }\end{array}$} & \multirow{2}{*}{$\begin{array}{l}P \\
\text { value }\end{array}$} \\
\hline & & Present & Absent & \\
\hline 1 & 71 & 5 & 66 & \multirow{2}{*}{$<0.05$} \\
\hline 2 & 47 & 15 & 32 & \\
\hline
\end{tabular}

Table 6 reveals the association of number of previous caesarean section with uterine scar dehiscence. As both variables are categorical, Chi-square test of independence was applied which was statistically significant $(\mathrm{p}<0.05)$.

\section{DISCUSSION}

The present study was designed to evaluate intraoperative maternal complication in repeat caesarean section like adhesions, scar dehiscence, excessive blood loss, difficult delivery of fetus and cesarean hysterectomy.

Modern obstetrics, for medical, social reasons has witnessed an increase in the primary caesarean section rates everywhere, giving a high risk pregnancy status to the subsequent pregnancy.

Complications of caesarean section can result from any number of factors including maternal and fetal health, timing of the procedure, surgical technique and obstretricians experience. Repeat caesarean section is associated with additional risks when compared with primary caesarean section. ${ }^{6}$ Intraoperative complications in repeat caesarean section (Table 2-6). 
In present study, following intraoperative morbidities were encountered- adhesions ( 1 caesarean section vs 2 caesarean section- 40.85 vs $65.96 \%$ respectively), thin LUS ( 1 caesarean section vs 2 caesarean section- 21.13 vs $36.17 \%$ respectively), advanced bladder (1 caesarean section vs 2 caesarean section - 15.49 vs $36.17 \%$ respectively), extension of uterine incision (1 caesarean section vs 2 caesarean section -9.86 vs $19.15 \%$ respectively), scar dehiscence (1 caesarean section vs 2 caesarean section -7.04 vs $31.91 \%$ respectively), excess blood loss (1 caesarean section vs 2caesarean section 7.04 vs $19.15 \%$ respectively), 1 case of placenta accrete was found in previous 2 caesarean section $2.13 \%$ ) which needed caesarean hysterectomy. uterine rupture and bladder injury seen in one patients of previous 2caesarean section.

In a study by Khusboo et al complication rate were adhesions $(35 \%)$, thin LUS (19\%), extension of uterine incision $(3 \%)$, postpartum haemorrhage $(5 \%)$ and placenta previa/ accreta $(5 \%){ }^{7}$

In a study by Joseph et al, the complication rate were adhesions (34\%), thin LUS (17\%), extension of uterine incision $(3 \%)$, postpartum haemorrhage $(5 \%)$, placenta previa $(3 \%)$ and placenta accrete $(2 \%){ }^{8}$

In a study by Farkhundah et al, dense adhesions were found in $27 \%$ cases, extremely thinned-out lower uterine segment was found in $11.6 \%$ cases, scar dehiscence was seen in $6.25 \%$ cases, ruptured uterus in $1.6 \%$ cases, placenta praevia in $2.5 \%$ cases, morbidly adherent placenta in $0.8 \%$ cases, bladder injury occurred in $0.8 \%$ cases while fetal demise (due to ruptured uterus) occurred in $1.6 \%$ cases. $^{9}$

The average operative time needed for a previous 1 caesarean section vs 2 caesarean section $42.01 \pm 0.5 \mathrm{vs}$ $55.03 \pm 2.6 \mathrm{~min}$ respectively) when adhesion present. It shows that there is an increase in average operative time in prescence of adhesion. Similar results were also observed by Joseph et al and Waheed $\mathrm{H}$ et al. . $^{3,8}$

Although peritoneal adhesions develop in the overwhelming majority of intra-abdominal and pelvic surgery. The incidence of adhesion development increases with the number of CS performed is shown in many studies. ${ }^{10}$ The most common adhesions found in the group are between bladder and uterus and also between uterus and omentum.

Majority of these cases were associated with increased bleeding due to increase in raw surface following adhesiolysis and increased operating time. Also, there is increased risk of adjacent injuries to adjacent tissue. ${ }^{11}$

\section{Bladder injuries in repeat cs}

For post caesarean pregnancy - chance of bladder injuries increases as number of caesarean section increases. Risk increases to $1.5 \%$ after 4 or more previous uterine incision. ${ }^{12}$ In the present study one cases of bladder injury was observed in patient with 2 previous caesarean section.

\section{Thin lower uterine segment}

Despite the advantages of lower segment CS scar, they are still relatively associated with poor healing. Juntunen and colleagues reported a significantly higher percentage of thin $(<2 \mathrm{~mm})$ lower uterine segment in patients undergoing repeat LSCS. ${ }^{13}$ Therefore, incomplete healing of the low transverse uterine incision as determined by transvaginal ultrasound may occur more frequently than earlier thought. In present study the thinned out LUS (1 caesarean section vs 2caesarean section - 21.13 vs $36.17 \%$ respectively). Similar results were noted by 11.6 $\%$, Joseph et al $17 \%, 18 \%$ in samar et al. ${ }^{8,9,14}$ There is positive relation between thinned out LUS and number of CS. Thus, chances of scar rupture increase with increasing number of CS. So, women with more number of CS should undergo Trans Vaginal Sonography to assess the scar thickness.

In the review by Kirkinen showed increased fenestration of the uterine scar with increased number of caesarean sections. ${ }^{15}$ Present study show (1 caesarean section vs 2 caesarean section -7.04 vs $31.91 \%$ respectively), cases of scar dehiscence. It is notable that risk factors for scar dehiscence such as multiple pregnancy and polyhydramnios were present in our patients and induction of labour was carried out in patients with one previous CS. The risk of uterine rupture in patients with one previous CS has been shown to increase with induction of labour. ${ }^{16}$ Poorly healed uterine scar might affect the regeneration of the isthmus of uterus and make it thinner, resulting in much thinner lower uterine segment scar in subsequent pregnancy. Thin lower uterine segment scar is likely to rupture during labor. Several recent reports suggest that USG evaluation of lower uterine segment can be used effectively to assess its integrity to predict the risk of Intrapartum rupture. ${ }^{17,18}$

Rozenberg et al found that LUS thickness correlated inversely with the risk of rupture and concluded that thickness more than $3.5 \mathrm{~mm}$ is protective against rupture. ${ }^{19}$ In a study by Samar et al concluded that there is actually no ideal cut off value that can be recommended for clinical purposes, even if the association of LUS thickness and uterine scar defect is strong. ${ }^{14}$ It is notable point that in present study scar dehiscence was high may be because women come as an emergency with history of previous one or two cesarean section were in labour or induction of labour was carried out in these patients

In present study 1 case of placenta accrete was noted. Similar observations were also made by Khusboo et al, Joseph et al and Waheed et al. ${ }^{3,7,8}$ Placenta accreta is a potentially life threatening obstetric condition that 
requires a multidisciplinary approach to management. The incidence of placenta accreta seems to parallel the increasing CS rate. Women at greatest risk of placenta accreta are those who have myometrial damage caused by a previous caesarean section. Diagnosis of placenta accreta before delivery allows multidisciplinary planning to reduce the potential maternal or neonatal morbidity and mortality. ${ }^{20}$

Two American studies showed the association of placenta previa and previous caesarean sections. They also confirmed the association of previous caesarean section with placenta accreta and hysterectomy. ${ }^{20}$ In present study the incidence of placenta accrete was $2.13 \%$

Silver RM found that in the presence of a placenta previa, the risk of placenta accreta was $3 \%, 11 \%, 40 \%, 61 \%$, and $67 \%$ for the first, second, third, fourth and fifth or greater repeat caesarean deliveries, respectively. ${ }^{21}$

Peripartum caesarean hysterectomy is almost performed as an emergency and associated with significant blood loss. In present study, one (2.13\%) cesarean hysterectomies was done Placenta accreta increases risk of hemorrhage and caesarean hysterectomy. ${ }^{22}$

\section{CONCLUSION}

In modern obstetric practice, objective is safe motherhood and healthy baby by proper management. From present study, it can be concluded that repeat caesarean sections are associated with increased morbidity.

Intraoperative complication which increase the risk of morbidity adhesion, placenta accreta, which can be decreased with advance surgical techniques as well as post operative care. It is prudent to involve a senior experienced obstetrician in repeat cesarean section.

The best way to reduce this is by reducing primary section rates specially where indication is maternal request by counselling patients. Patients with previous Caesarean section should be considered as high risk and should be counseled for regular antenatal check-up and difficulties associated with repeat cesarean section.

Vaginal birth after CS option should be recommended to these patients whenever possible. It is important to educate public regarding advantage of a regular antenatal care and to train birth attendants to learn to detect the high risk cases in peripheral centers and directing them to referral centers.

Further clinical studies are needed to evaluate not only the effects of surgical techniques, and intraoperative management but also to investigate their effects on perioperative morbidity that is associated with caesarean section.
Funding: No funding sources

Conflict of interest: None declared

Ethical approval: The study was approved by the Institutional Ethics Committee

\section{REFERENCES}

1. MacDorman MF, Menacker F, Declercq E. Cesarean birth in the United States: epidemiology, trends and outcomes. Clin Perinatol. 2008;35(2):293-307.

2. Lynch CM, Kearney R and Turner MJ. Maternal morbidity after elective repeat caesarean section after two or more previous procedures. Eur J Obstet Gynecol Reprod Biol. 2003;106:10-13.

3. Waheed F, Muhabat Q, Baloch R, Ahmed W. Maternal complications in repeated caesarean section. Innova J Med Health Sci. 2016;6(2):49-52.

4. Bates GW Jr, Shomento S. Adhesion prevention in patients with multiple cesarean deliveries. Am J Obstet Gynecol. 2011;205(6):19-24.

5. Marshall NE, Fu R, Guise JM. Impact of multiple cesarean deliveries on maᄀternal morbidity: a systematic review. Am J Obstet Gynecol. 2011;205(3):262-8.

6. Zia S, Rafique M. Intra-operative complications increase with successive number of cesarean sections: Myth or fact. Obstet Gynecol Sci. 2014;57(3):187-192.

7. Kushboo, Singh S, Karan A. Intra-op complications: primary versus repeat cesarean section. IOSR-JDMS. 2017;16(4):30-4.

8. Joseph S, Gilvaz S. A Comparative Study on Intra Operative Problems during Primary versus Repeat Caesarean Sections. Sch J App Med Sci. 2016;4(2A):303-10.

9. Khursheed F, Sirichand P, Jatoi N. Intraoperative complications encountered in patients with repeat cesarean section. JLUMHS. 2009 Jan;8(01):76.

10. Awonuga AO, Fletcher NM, Saed GM, Diamond MP. Postoperative adhesion development following cesarean and open intra-abdominal gynecological operations: a review. Reprod Sci. 2011 Dec;18(12):1166-85.

11. Nisenblat V, Barak S, Griness OB, Degani S, Ohel G, Gonen R. Maternal Compilations Associated With Multiple Cesarean Deliveries. Obstet Gynecol. 2006;108:21-6.

12. Scotti RJ, Young JN, Ho MH, Urologic complications. In: O'Grady JP, Gimovsky ML, Bayer-Zwirello L, Giordano K (eds.): Operative Obstetrics $\quad\left(2^{\text {nd }}\right.$ ed). Cambridge: Cambridge University Press. 2008;608-637.

13. Juntunen K, Makarainen L, Kirkinen P. Outcome after a high number (4-10) of repeated caesarean sections. BJOG. 2004;111(6):561-3.

14. Sarsam SD, Kadem HA. Measuring lower uterine segment thickness using abdominal ultrasound to predict timing of cesarean section in women with scarred uterus at elwiya maternity teaching hospital. KCMJ. 2013;9(2):9-13. 
15. Kirkinen P. Multiple caesarean sections: outcomes and complications. $\mathrm{Br} \mathrm{J}$ Obstet Gynaecol. 1988;95:778-82.

16. Lydon-Rochelle M, Holt VL, Easterling TR and Martin DP. Risk of uterine rupture during labor among women with a prior cesarean delivery. N Engl J Med. 2001;345(1):3-8.

17. Cheung VYT, Constantinescu OC and Ahluwalia BS. Sonographic evaluation of the lower uterine segment in patients with previous caesarean delivery. J Ultrasound Med. 2004;23:1441-7.

18. Bojold E, Jastrow N, Simoneau J, Brunet S and Gauthier RJ. Prediction of complete uterine rupture by sonographic evaluation of the lower uterine segment. J Obstet Gynecol. 2009;201:320.

19. Rosenberg P., Goffinet F, Phillipp HJ. Ultrasonographic measurement of lower uterine segment to assess risk of defects of scarred uterus. Lancet. 1996;347(3):281.
20. Placenta accreta. Committee Opinion No. 529. American College of Obstetricians and Gynaecologists. Obstet Gynecol. 2012;120:207-11.

21. Silver RM, Landon MB, Rouse DJ, Leveno KJ, Spong CY, Thom EA, et al. Maternal morbidity associated with multiple repeat cesarean deliveries. National Institute of Child Health and Human Development Maternal-Fetal Medicine Units Network. Obstet Gynecol. 2006;107:1226-32.

22. Ashraf R, Gul A, Bashir A, Tajammal A. Comparison of maternal complication in elective vs. emergency caesarean section. Ann King Edward Med Coll. 2006;12:288-90.

Cite this article as: Somani SS, Sudhir S, Somani SG, Bushra. A study of intra-operative maternal morbidity after repeating caesarean section. Int $\mathbf{J}$ Reprod Contracept Obstet Gynecol 2018;7:291-6. 